\title{
Review on Structure-Conduct-Performance of Coffee Market in Ethiopia
}

\author{
Adem Kelifa \\ Lecturer, Department of Agricultural Economics, Gambella University; Gambella, Ethiopia
}

\begin{abstract}
Coffee is the most important produced and traded commodities in the world. It serves as means of livelihood for majority smallholder farmers in Africa as well as Ethiopia. It is aimed to review structure-conduct-market performance of coffee market in Ethiopia. In this regard, Structure-conduct-performance is the common methods of analyzing marketing systems. The coffee market structure was characterized by high barrier to entry, differentiated product and dominated by a few traders. It mainly falls under weak and strong oligopoly market. The markets conduct review shows pricing and purchasing strategies was mainly determined by traders. The majority of the profit margin goes to private exporters and producers acquired least profit margin. Therefore the review recommended that a means of making the market more competitive should be created to enhance bargaining power of smallholder coffee producers and letting them acquire high share of profit margin from participation in coffee marketing.
\end{abstract}

Keywords: Coffee, Ethiopia, Structure conduct performance

DOI: $10.7176 / \mathrm{FSQM} / 86-04$

Publication date: April $30^{\text {th }} 2019$

\section{Introduction}

\section{Background and Justification}

Coffee is one of the most important traded commodities in the world, and the sector's trade structure and performance have large development and poverty implications, given the high concentration of production by small-holders in poor developing countries (Minten et al., 2014). The main coffee producing regions in the world are Central and South America, Southeast Asia and Africa. The two species of coffee beans that are most widely cultivated (accounts for almost all cultivation) are the "Arabica", which has a distinctively sour flavor and the "Robusta", which has a somewhat bitter taste and is inexpensive compared to Arabica (Kikkawa, 2018).

The coffee farming provides a livelihood and employment for approximately 7 million households in Africa, most of which are smallholders. Ethiopia is the leading Arabica coffee producer in Africa, the fourth largest worldwide after Brazil, Colombia and Honduras in Arabica coffee production. Whereas, interms of total coffee production (both Arabica and Robusta), Ethiopia ranks sixth in the world and first in Africa followed by Uganda which ranks eighth in the world during 2016/17 and 2017/18 production year (USDA, 2018). In terms of types of coffee produced, Ethiopia is an Arabica-producing country and coffee farmers in Uganda predominantly cultivate Robusta coffee (ICO, 2017).

Ethiopia is the leading countries in Africa by coffee exports. Accordingly, the country ranks first in Africa and eighth in the world in total coffee bean exports. In spite of this, Ethiopia is leading producer and exporter in Africa, the country also ranks first in Africa and tenth in the world interms of domestic coffee consumption (USDA, 2018). Coffee export accounts for about one-third of the country's export earnings. It accounts about 206,700 metric tons during 2014/15 marketing year (Tefera, 2016).

Even though the government deals with coffee marketing, farmers faced a lot of problems (Aklilu and Ludi, 2010). For instance, insufficient regulation of price where collectors and suppliers set their own price which is usually less than which announced by government.

Coffee supports millions of farming families as source of cash income and providing employment opportunity throughout the country, especially in the western, southern, and south-eastern parts of the country (UNIDO, 2014). However, the marginal income earned by farmers is not enough for them to invest in more environmentally sustainable production systems and to compensate for low food production and nutritional needs (EN, 2017). Despite economic and social significance, coffee producers in Ethiopia have historically received a very small share of the export price of green coffee due to heavy government intervention and high marketing and processing costs Tadesse and Feyera (2008).

The objective of this paper was to review structure-conduct- performance of coffee market in Ethiopia

\section{Discussion}

\subsection{Overview of Coffee in Ethiopia}

Coffee production is Ethiopia's main industry, with production of 400,000 tons of coffee during 2016 production year (Kikkawa, 2018). Coffee plays a major role in Ethiopia's economy and as the country's leading export is an important source of foreign exchange. In addition to its economic importance, coffee is deeply intertwined in the 
country's social, cultural and historical identity (Tefera, 2016). Ethiopia is unique among the world's coffee producing countries in that around $50 \%$ of the coffee it produces stays within the domestic market for consumption (UNIDO, 2014; ECFF, 2017).

Coffee is mostly grown in two regions of the country, namely Oromia and Southern Nations, Nationalities and People Regions (SNNPR). Ninety five percent (95\%) of Ethiopia's coffee is produced by smallholder farmers while the remaining five per cent is grown on modern commercial farms (UNIDO, 2014; EN, 2017). with a lesser amount but significant expansion potential in the Amhara region (EN, 2017). The major types of coffees are: Yirgacheffe, Harar, Sidamo, Limu, Jimma, Tepi, Bebeka, Lekmpti, Illubabor, Gimbi, Kaffa Forest, Gemadro, Godere, Bench, Bale, Anderacha, Amaro, Aris and Kochere (UNIDO, 2014).

The majority of coffee production is from the forested main coffee zone of the South West, followed by the Sidamo (including Yirgacheffe) coffee area in the South East coffee zone. Coffee farming in Ethiopia takes place over a vast area under a different production system (ECFF, 2017). Accordingly, Coffee production in the country is categorized as forest coffee, semi-forest coffee, garden coffee and plantation coffee production systems (MoT, 2012; Tefera and Tefera, 2014)

Ethiopia mainly exports green coffee beans with only a very small amount of roasted beans. Most exports are going to Germany, Saudi Arabia, Japan and the United States (Tefera, 2016). Ethiopia mainly exports green beans with only a very small amount of roasted beans. Ethiopian coffee is 70-80 percent unwashed or sundried and 2030 percent is washed coffee (Tefera and Tefera, 2015). Coffee export sales pass through three consecutive channels local, ECX, and International market to reach its final destination (Tefera, 2016).

\subsection{Concept of Structure-Conduct and Performance}

The Structure-Conduct-Performance (S-C-P) paradigm sometimes called the traditional industrial organization was a principal approach to study the industrial organization (IO) during the second half of the 20th century (Haji et al., 2011). Structure-Conduct and Performance model is one of the most common and pragmatic methods for analyzing marketing systems. It analyzes the relationship between functionally similar firms and their market behavior as a group and, it is mainly based on the nature of various sets of market attributes and relations between them and their performance (Scarborough and Kydd, 1992).

\section{Market structure}

The structure of the market refers to characteristics of the organization of the markets that seem to exercise strategic influence on the nature of competition and pricing within the market (Pomeroy and Trinidad, 1995). According to Kohls and Uhl (1985), as a rule of thumb, four largest firms concentration ratio of $50 \%$ or more indicates strongly oligopolistic industry. While 33-50 \% indicates weak oligopoly and less than that (competitive industry) was used to determine coffee market structure. Although four firm concentration ratio is the commonly used one, both four and eight firm concentration ratio was employed by Minten et al. (2014) to determine market structure of coffee export in Ethiopia. There four relevant aspects of market structures include the degree of seller concentration, the degree of buyer concentration, the degree of product differentiation, and the condition of entry (Scott, 1995).

\section{Market conduct}

Conduct refers to firm behavior like pricing and selling policies and tactics; overt and tacit inter-firm cooperation, or rivalry and research and development activities. If horizontal relationships between similar marketing enterprises are the basis for examining the structure of the market, the nature of vertical relationships of exchange shades light on the conduct of market participants (Scarborough and Kydd, 1992). Market conduct refers to the patterns of behavior that enterprises follow in adopting or adjusting to the markets in which they sell or buy (Bain, 1968). Market conduct is exceedingly complex, encompassing as it does virtually all human decision masking within business organizations and, by extension, household, on top of the market structure, the legal environment and the internal organization of the business enterprise influence the market conduct (Amha, 1994). Due to this fact, there are no agreed upon procedures for analyzing the elements of market conduct (Scott, 1995). Despite lack of commonly agreed model, various researchers used pricing and purchasing strategies to analyse market conduct.

\section{Market Performance}

Market performance refers to the impact of structure and conduct on prices, costs, and volume of output (Pomeroy and Trinidad, 1995). Performance of the market is reflection of the impact of structure and conduct on product price, costs and the volume and quality of output (Cramers and Jensen, 1982). The main indicators of market performance are net return and marketing margin (Amha, 1994).

\subsection{Structure-Conduct-Performance of Coffee Market in Ethiopia}

The focus of this review is to provide an empirical evidence of the structure conduct performance of coffee market in the Ethiopia.

\subsubsection{Market Structure}

Market share

The structure of coffee marketing system in Ethiopia are characterized by the presence of individual coffee farmers 
to the production side and coffee marketing cooperatives, Unions, wholesalers/suppliers and Exporters to the marketing side (Temtime, 2016).

The conducted study Shumeta et al. (2012) on Analysis of Market Chains of Forest Coffee in Southwest Ethiopia employed four form concentration ratios to analyse the degree of coffee market concentration for the local coffee wholesalers in Gera and Shebe woreda of Jimma Zone. The result of four firm concentration ratios (CR4) of wholesaler was $40.85 \%$ and 29.65 in Gera and Shebe respectively. This implies that a market structure of coffee in Gera is more competitive compared to Shebe woreda.

Belete (2014) estimated the concentration ratio for traders in coffee markets at Yirgalem and Hawassa. Accordingly, primary coffee market is characterized by unconcentrated suppliers due to the fact that coffee was mainly supplied to the market by a numbers of farmers and action of one producer does not affect function of others. Conversely, a few traders dominate the market and the top four traders controlled $65.3 \%$ of the coffee market. This characteristic makes the coffee market structure in the area fall under strongly oligopolistic market as suggested by Kohls and Uhl (1985).

According to Gachena and Kebebew (2014) four firm's concentration ratio (four largest coffee collectors) in the Sheko and South Bench Woredas were about $68.8 \%$ and $60.33 \%$ respectively. This means that majority of total volume of purchased coffee was handled by collectors. This characteristic makes market at collector level strongly oligopolistic in both woredas and unconcentrated at producer level due to the fact that no producer affects the function of other producers.

Gebre (2017) conducted study on Analysis of coffee market chain in Gewata District, Kaffa Zone, Southwest Ethiopia. He found coffee market traders' concentration ratio CR4 estimated to be 40.86 percent. Therefore, it implies that coffee market structure in the study area to be lose (weak) oligopoly market structure.

Gashaw (2018) conducted study on structure conduct and performance of coffee market in Jimma Zone. The result of four firm's concentration ratio shows that the four largest suppliers in Limmu Kossa, Gomma, Manna and Limmu-Seka districts mobilized $60.6 \%, 52.4 \%, 51.2 \%$, and $58.9 \%$ of the total volume of red cherry coffee purchased respectively. While that of dry cherry coffees were found to be $55.7 \%, 38.6 \%, 36 \%$, and $45.4 \%$ for Limmu Kossa, Gomma, Manna and Limmu-Seka respectively. This figure implies that market structure for red cherry coffee is categorized under strongly oligopolistic one and that of dry cherry coffee is weak oligopoly except for Limmu Kossa which falls under strong oligopoly market structure. Therefore it could be concluded that coffee market structure in the area fall under Oligopoly market.

Minten et al. (2014) calculated coffee export concentration ratio of four largest firm and eighth largest firm in Ethiopian coffee export market between 2006 and 2013. Their result shows the decrements in the share of coffee exports coming from parastatals since the end of 2009 due to privatization of state farms (Bebeka and Teppi and Limu Coffee Plantations of the Coffee Plantation and Development Enterprise, which were privatized in 2011/12, 2012/13 and 2014 respectively) and increments in the number of private exporters from 100 in 2008 to 175 in 2012.

The largest eight firm concentration ratio (CR8) before 2008 was approaches 60 percent on average whereas; at the end of 2013 it becomes about 40 percent. The results of four largest four firm concentration ratio (CR4) before 2008 on average was about 40 percent and 25 percent at the beginning of 2013 (Minten et al., 2014). This implies that, the share of the largest four and eight exporters in the coffee market have decreased significantly during the past year. However the finding is not in line with World Bank (2014) report which shows the largest exporters (selling more than 5 million USD per annum) accounted for nearly $80 \%$ of coffee exports and the remaining 20 percent of the coffee market with sales ranging from US\$100 thousand to US\$500 thousand per year was occupied by small companies. This reveals that the largest exporter dominate huge amount of coffee export and the market share of small companies are too low.

\section{Barriers to entry}

The government's coffee policy mainly deals with licensing exporters, wholesalers and roasters, while monitoring and promoting coffee exports, and controlling the hard currency generated from these sales. There are storage limits in place to prevent traders from holding their stocks too long. Marketing of export-grade coffee on the local market is prohibited even when domestic prices are higher than the international market (Tefera, 2016). Besides, World Bank (2014) report indicates that it is difficult for new entrants to penetrate in the Ethiopian coffee market. This implies that licencing requirement is one barrier to enter coffee marketing in Ethiopia.

Empirical study conducted by Gachena and Kebebew (2014) in Sheko and South Bench; Belete (2014) in Dale district of Southern Ethiopia, Gebre (2017) in Gewata district of Kaffa Zone and Gashaw (2018) in Jimma zone also reveals that the licencing procedure, huge capital for start-up and buying trade seat from ECX, the nature of the coffee business itself were identified barriers to entry for new entrants in the coffee market.

The capital requirement discouraged traders from expanding their scale of operation, achieving greater efficiency and engaging in the long-run storage needed (Gachena and Kebebew, 2014). Similarly, Coffee traders noted that the main entry barrier in the coffee marketing in eastern Hararghe is coffee trading requires huge capital investment (Haji et al., 2011). 


\section{Product differentiation}

Ethiopia has a natural abundance of indigenous coffee varieties, numbering in the thousands and bred over millennia of natural and human cultivation. This makes Ethiopia the recognized home of specialty coffee, where more market differentiation exists. It can be said that Ethiopia is endowed with specialty advantage (USAID, 2010). Unlike many coffee growing countries, Ethiopian coffee varieties are differentiated by agro-ecological and local conditions; shape, acidity, body, flavor, aroma and processing method, and they are generally auctioned by their corresponding origin. In particular, Ethiopian coffee is traded in the world market based on their origin of production (e.g., Sidama, Yirgachefe, Harar, Jimma, Lekemt, Teppi, Limu and Bebeka). Besides this branding also considered to differentiates the product Ethiopia owns trademark rights for the distinctive fine coffee of Sidamo, Yirgacheffe and Harar brands since 2008 (Hernandez et al., 2015). Coffee export market is highly differentiated in Ethiopia, with quality premiums being offered for washing, grades, certification (Organic, fair trade and Rainforest Alliance), and specific geographical indications (Minten et al., 2014). Therefore it can be concluded as different certification scheme, origin of production, grading, and owning trademark rights on distinctive fine coffee makes coffee differentiable product.

\subsubsection{Market Conduct}

Price setting within Ethiopia involves two main stages, at the primary transaction centers where farmers transact with processors (akrabies) and at the Ethiopian Commodity Exchange (ECX) auction where processors sell to exporters through their brokers. Export prices at which exporters sell to international traders or roasters are closely related to EXC prices but may differ particularly for certain grades. The ECX price system's focus is on price transparency, i.e. the efficient transmission of ECX prices to the farm gate, without price stabilization measures or instruments to deal with price instability by local actors (Troster and Staritz, 2015).

The price setting mechanism in the producers market is largely determined by the benevolence of buyers. Producers have a low bargaining power to influence price due to their limited capital and access to market (price) information. In the coffee export market, the selling prices of Exporters are largely determined by the international market price (New York Price) and are easily accessed by exporters from the internet and other published sources (Shumeta et al., 2012). The international price is the New York Arabica coffee price indicator calculated by the International Coffee Organization on the basis of different Arabica coffees traded (Hernandez et al., 2015).

Price setting at the local market was mainly done by coffee traders but there was a few traders negotiate with producers and look for competitors before price setting in Sheko and South Bench woredas (Gachena and Kebebew, 2014). The wholesaler controls a volume of purchase through distributing large amount of money to coffee collectors and brokers. While collectors control purchases through friends and moving from home to home. Belete (2014) point out that market power in setting price at local level is vested in the hand of coffee traders. Due to seasonal nature of production, large volume of coffee is supplied to the local market during harvesting seasons which decreases the bargaining power of producers.

Gebre (2017) found pricing strategies of all traders not similar at all. Accordingly, He found that majority of traders set their own buying price without negotiation and discussing with producers. Besides, a few traders who discuss with other trader in price setting and other made negotiation with both farmers and traders themselves in setting price. According to Gashaw (2018) price setting and purchase strategy was different among different actors in market channels. Suppliers fix more or less the same price. This activity reduces producer bargaining power by weakening farmers' ability to choose alternative better prices. On other hand, Cooperatives and unions made some efforts to benefits smallholder farmers by acting as a catalyst in setting high price so that other suppliers follow.

The prices offered in the Ethiopian Commodity Exchange (ECX) markets influence the price setting in the producer market. However, the ECX does not have the mandate to set export prices. But, since the ECX follows the international coffee price for price setting, it most likely influences the price-setting strategy of the exporters (Demise et al., 2017).

\subsubsection{Market Performance}

The performance was hindered by poor market structure, low productivity of grower's fields, and poor quality control under the imperial regime. Under the military regime, it was hindered by limited competition on the market, smuggling, collapse of world price of coffee and shifting from production of coffee to khat due to high taxes. During the military government between 1974 and 1980 there was no major improvements in the country's export performance but short improvement has been observed between 1986 and 1991(Boansi and Crentsil, 2013). Coffee export performance was improved during the year between 1995 and 2001 due to reduction in export and farm taxes, abolition of farmer's quota and withdrawal of constraints on trading activities of private traders attracted exporter and intermediaries as well as more farmers into production of coffee. Then after Authorizing engagement of Cooperative Unions in direct exports, and private exporters to engage in domestic marketing of coffee at market prices made an increase in the number of exporters and intermediaries in the supply chain from the year 2001 onwards. This results in price risk due to the highly volatile nature of coffee price and involvement of a numerous actors and process in the chain leds transaction costs and resulted in Gradual decline in the country's export performance from 2001 to 2010 (Boansi and Crentsil, 2013). 
In total, 85 to 90 percent of all coffee export volume is traded via exporters. Cooperative output may be exported through the EXC or directly. Direct exports by cooperatives amount to around 5 to 10 percent of all coffee exports (Minten et al., 2014). Coffee producers in Ethiopia have historically received a very small share of the export price of green coffee due to heavy government intervention and high marketing and processing costs. Prior to 1992, coffee production and marketing in Ethiopia was centrally controlled under the ministry of coffee and tea development. Producers had to sell their coffee at fixed price and fixed times. The Ethiopian Coffee Marketing Corporation (ECMC) handled the vast majority of the crop. The corporation put a substantial wedge between the producer price and the world price of coffee by imposing an implicit tax on producers (Tadesse and Feyera, 2008).

Among the different market chain, namely producers, local assemblers, local wholesalers, wholesalers in Jimma, wholesalers in Addis Exporters, Shumeta et al (2012) found exporters taking the largest gross margin followed by the wholesalers in Addis. Their finding shows that producers were not benefited from the market compared other actors.

As the study conducted by Gebre (2017), producers share is $76.88 \%$ with marketing agents like rural collector and private traders. On other hand in the market which comprises only producers and private trader, the margin share producers is $81.28 \%$ The consistent with this results, Belete (2014) found the gross marketing margin/benefits for coffee producers in the market with two marketing agents namely, producers and wholesaler rather than three marketing agents namely, producers, Coffee collectors and wholesaler. This implies that market with a number of marketing agents produces lower producer's share of marketing margin then market with a few marketing agents.

Temtime (2016) also found that coffee supplied to the export market by a very large number of intermediaries in the market causes to high transaction cost, gaps in the transfer of market information, high product cost and late shipment. According the work of Gashaw (2018), the highest percentage share of profit is captured by cooperative union followed by private exporter both case of washed and unwashed coffee. It shows very low profit share in coffee producers compared to other actors in the case of washed coffee. In the case of unwashed coffee, the smallest share of profits goes to primary cooperative followed by suppliers. In addition to this, cost of production at the producer level is the major portion of all costs along the marketing chain.

Temtime (2016) used Ethiopian coffee export data during the year 2011-2015 and the result reveals that the highest performance in quantity of exported coffee was recorded in the year 2013 and the lowest was recorded in the year 2012. This coffee export performance has comprised the share of all actors which involved in coffee export. Those are producers, cooperative unions and exporters. He computed the share of each actor in country's exported coffee during the year 2011, 2012, 2013, 2014 and 2015 value (in dollar). Accordingly, the smallest share of exported coffee goes to producer whereas, the highest share of exported coffee was in the hand of exporters followed by cooperatives. This indicates that, the exporters dominate coffee export market in Ethiopia by handling a large volume of exported coffee.

\section{Conclusion and the way forward}

Ethiopia is prominent coffee producer, consumer and exporter in the world as well as in Africa. It plays a great role in enhancing total Gross Domestic Product (GDP) of the country by augmenting foreign direct investment and export share. This paper provides the empirical studies on structure-conduct-performance of coffee market in Ethiopia. The structure-conduct-performance results from different empirical studies shows coffee market in Ethiopia is almost fall under oligopoly market structure and unconcentrated at producer level. Price setting in coffee marketing is mainly determined by the will of buyers (traders) at levels. The coffee marketing performance results indicates that large marketing margin is handled by exporters and the margin captured by coffee producers is very low compared with other marketing agents. The review also shows increments in the numbers of marketing agent leads to decrease producers marketing gross margins.

Therefore, the means of making market more competitive should be created since it enable producers to capture more profit margins; cooperative marketing agents should be strengthened because they play a great role in terms of benefiting producers during price setting. Coffee producers should be given training on producing quality coffee since it is assumed to increase their bargaining power.

\section{References}

Aklilu, A. and Ludi, E., (2010). The Effect of Global Coffee Price Changes on Rural Livelihoods and Natural Resource Management in Ethiopia. A Case Study from Jimma Area. NCCR North-South Dialogue.

Amha, W. (1994). Food grain marketing development in Ethiopia after the market reform 1990: a case study of Alaba Siraro District. Berlin (Germany), Verlag Koster, 1994.

Bain, J.S.(1968). Industrial organization. $2^{\text {th }}$ Edition, John Wiley and Sons, New York.

Belete, W. (2014). Market Chain Analysis of Coffee in Dale District of Southern Ethiopia. An MSc Thesis Presented to the School of Graduate Studies of Haramaya University, Haramaya, Ethiopia. 
Boansi, D. and Crentsil, C. (2013). Competitiveness and determinants of coffee exports, producer price and production for Ethiopia. August, 2014

Cramer, G. L. and W. Jensen (1982). Agricultural economics and agribusiness, 2nd Edition. McGraw Hill Book Company, USA. 222p.

Demise, T., Natanelov, V., and D'Haese, M (2017). Market integration and price transmission under institutionalized Ethiopian coffee market: Evidence from nonlinear ARDL model. Gent University, Belgium. Accessed date, October 20, 2018. Available at www.eeaecon.org/sites/default/files/forms/Tinsae.pdf.

ECFF (2017). International coffee forest forum. Coffee Farming and Climate Change in Ethiopia Impacts, Forecasts, Resilience and Opportunities. Accessed at Oct. 13, 2018

EN (European Union) (2017). Action document for European Union. Coffee Action for Federal Democratic Republicof Ethiopia. Accessed date: oct. 15, 2018. Available at: https://ec.europa.eu/europeaid/sites/devco/files/annex iv.pdf

Gachena, D. and Kebebew, S. (2014). Evaluating Coffee Market Structure and Conduct in Bench - Maji Zone, South West Ethiopia. J. of Agri. Econ, Extension and Rural Dev't, Vol. 2(5): pp. 156163

Gashaw B. A. (2018). Exploration of Structure-Conduct-Performance of Coffee Market System in Ethiopia. The Case of Jimma Zone. J. of Marketing and Consumer Research. Vol.44, Pp. 18-28.

Gebre (2017). Analysis of Coffee Market Chain: The Case of Gewata District, Kaffa Zone, Southwest Ethiopia. MSc Thesis at Haramaya University, Ethiopia.

Haji J., Gelaw F., and Kassa B. (2011). Review of the Economic role of prices and approaches to the study of Agricultural marketing. Agricultural Marketing and Price Analysis Module 1. Haramaya University School of Agricultural Economics and Agribusiness. April, 2011

Hernandez, M., Lemma, S. and Rashid, S. (2015). Ethiopian Commodity Exchange and the coffee market: Are local prices more integrated to global markets? No. 211732. International Association of Agricultural Economist.

ICO (International Coffee Organization) (2017). Value addition in the African coffee sector. International Coffee Council $120^{\text {th }}$ Session 28 and 29 September 2017. Yamoussoukro, Côte d'Ivoire

Kikkawa, R. (2018). Ethiopia Coffee Business. Sub-Saharan Report [Business Plus]. Marubeni Research Institute, January 23, 2018. Accessed date: October, 12. 2018.

Kohls, R., and N. Uhl (1985). Marketing of agricultural products. 5th Edition. McMillian Publishing Company, NewYork, USA.

Minten, Mekdim D, Ermias E, Tadesse K (2014). Structure and performance of Ethiopia's coffee export sector. Working Paper 66, Addis Ababa, Ethiopia

MOT (Federal Democratic Republic of Ethiopia Ministry of Trade) (2012). Coffee Opportunities in Ethiopia. Addis Ababa, Ethiopia country Profile

Pomeroy, R.S., and A.C. Trinidad, 1995. Industrial organization and market analysis: pp 217-238. In: G.J. Scott (eds). Prices, Products, and People: Analyzing Agricultural Markets in Developing Countries. Lynner Reinner publishers, Boulder, London.

Scarborough, V. and J. Kydd (1992). Economic analysis of agricultural markets. A manual of marketing series 5, Chatham, UK: Natural Resource Institute: $172 \mathrm{p}$.

Schmitz, H. (2005). Value chain analysis for policy makers and practitioners. International Labour Office and Rockefeller Foundation, Geneva, Switzerland.

Scott, G.J. (1995). Prices, Products and People: Analyzing Agricultural Markets in Developing Countries. Lynne Reinner Publishers, Boulder, London. 498p.

Shumeta, Z., Urgessa K. and Kebebew, Z (2012). Analysis of Market Chains of Forest Coffee in Southwest Ethiopia. Academic J. of Plant Sc. 5 (2): 28-39

Tadesse, W. and Feyera, S. (2008). Sustainable Management and Promotion of Forest Coffee in Bale, Ethiopia. SOS Sahel/FARM-Africa. Addis Ababa, Ethiopia

Tefera A (2016). Ethiopia. Coffee Report. Production and Exports Remain Steady. GAIN Report Number: ETET1615. USDA.

Tefera, A. and Tefera, T (2015). Ethiopia Coffee Annual Report, GAIN Report Number: ET-1514. USDA.

Tefera, A., Tafera, T (2014). Ethiopia. Coffee Annual Report, Gain Report ET-1402, USDA.

Temtime, A. (2016). Assessments of Coffee Marketing Chain and its export performance in Ethiopian GDP. Thesis submitted to St. Mary's University School of graduate studies. Addis Ababa, Ethiopia.

Tröster, B. and Staritz, C (2015). Global commodity chains, financial markets, and local market structures: Price risks in the coffee sector in Ethiopia (No. 56). Working Paper, Austrian Foundation for Development Research (ÖFSE).

UNIDO (United Nation Industrial Development Organization) (2014). Improving the Sustainability and Inclusiveness of the Ethiopian Coffee Value Chain through Private and Public Partnership. Project of FDRE. 
Available at https://open.unido.org/api/documents/2264814/download/final\%20project\%20document

USAID. (2010). Ethiopian Coffee Industry Value Chain Analysis Profiling the Actors, Their Interactions Costs Constraints and Opportunities. Chemonics International profile.

USDA (United States Department of Agriculture) (2018). World Coffee Markets and Trade report. Accessed date: Oct. 13, 2018.

World Bank (2014). Third Ethiopia Economic Update. Strengthening Export Performance through Improved Competitiveness. June, 2014. 